\title{
The use of the Delphi survey as a research tool in understanding church trends
}

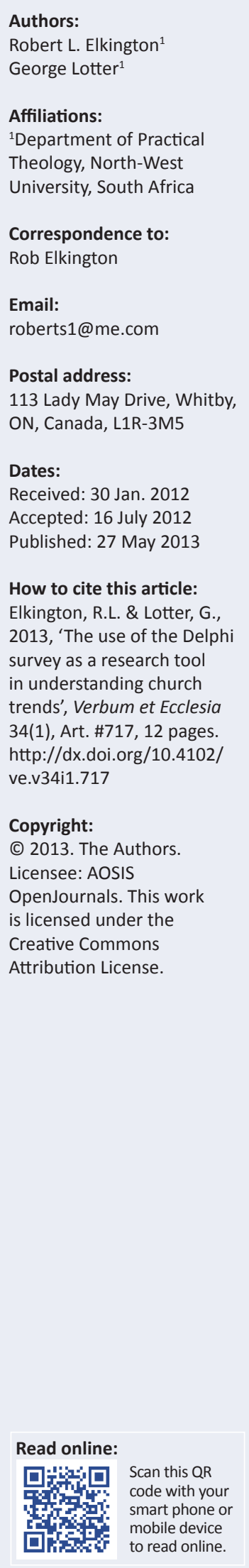

In the practical theological research process, as in most disciplines, extant literature is vital in assisting a researcher to formulate a foundational understanding of the topic under review. A literature review is also valuable in understanding the meta-theoretical aspects of the research topic. What does a researcher do, though, if there is little current literature on the topic under scrutiny? If there is a small corpus of literature around a subject, the Delphi method can serve as an extremely helpful research tool. This article discussed the use of the Delphi survey in a practical theological research endeavour and surveyed its history from inception to current usage. The article also reviewed the various types of Delphi survey and supported the use of the Lockean Delphi survey in this particular example of practical theological research. The article finished with an actual Delphi survey of Canadian Evangelical church pastors as an example of how the Delphi method can be used as a research tool in practical theology. The article concluded that the Delphi survey is an extremely useful research tool across the wide domain of social science research.

\section{Introduction}

How does a researcher develop a sound knowledge base around a topic that is either relatively new or has not been the subject of much scrutiny and hence does not have a solid range of literature to guide the researcher? This is the dilemma this author faced when a literature survey of current (1998-2011) Canadian literature on the growth or decline of the Evangelical churches in Canada, which form a part of the monolith we shall term the 'Evangelical Church', rendered sparse results. In an attempt to offset this deficit in the literature, a Delphi survey was designed and deployed amongst Canadian church ministry 'experts' - as defined (Skumolski, Hartman \& Krahn 2007:4) by the Delphi criteria. The purpose of this Delphi survey was to garner current Canadian practitioners' perspectives on the state of the Evangelical Church in Canada. The Delphi method itself is explained in more detail in the next section. The goal of this article is to assist the reader in gaining an understanding of the value of the Delphi process, in which 'experts' are surveyed in a series of two refined iterations with regard to what they each perceive to be the reasons for the decline of the Evangelical Church in Canada.

\section{Qualitative research of a large and complex issue}

Why are the Evangelical churches in Canada, in particular, in decline? Linear causation (Lincoln \& Guba 1985:54) is not sufficient to answer this question, since the Canadian Evangelical Church is a complex organism comprised of many smaller complex organisms known as 'local churches'. Further complexity is added since each local church organism is in turn comprised of a network of believers and adherents, who carry with them their own needs, perspectives, struggles and complex set of realities that affect the local church they belong to. This realisation of the layered complexity of the Evangelical Church in Canada gives rise to two important aspects of complex adaptive systems, and complexity theory (Lucas 2006) as it relates to the post-Christendom postmodern church of the 21st century. Firstly, linear prediction has given way to a non-linear world which means we cannot control the environment in such a way that we will produce expected outcomes. Secondly, in a complex adaptive system, '[d]iverse and integrated approaches to the problem are crucial. In many cases single approaches to the problem may lead to counterproductive results' (Hegazi, Hashish \& Ahmed 2009). The linear approaches or solutions are recommended by modernist practitioners (Borden 2003; Kaiser 2006) who believe the church still functions within the Christendom framework - perhaps because they are not fully aware of the complexity (Senge 2006:68-91) of both the church as an organism and the secular, postmodern environment in which the church now finds itself. With an attempt to acknowledge this complexity the research process utilised in this article employs a qualitative study that probes the interactions of mutual causality (Lincoln \& Guba 1985:54). Added to the notion of mutual causality is the further complex dimension of the interconnectedness of macro-environmental factors that are impacting the Canadian Evangelical Church, and therefore this article also 
employs a holographic image concept (Lincoln \& Guba 1985:52) rather than seeking a mechanical image concept. The holographic image conception of the research process is particularly germane to the Delphi method and thus it is explained in more detail in another section.

The decline of the Evangelical Church in Canada may incorporate many intersecting factors, especially since the church itself is both a living organism and an organised system. As a living organism it is affected by its macro-context and its internal functions - a change to either can readily spell decline and disintegration or health and flourishing. This also means that one cannot ascribe any single causation to either the decline or the health and growth of an organism, such as the Evangelical Church in Canada. In a bid to inquire into the nature of the various mutual causes for decline, the Delphi method, a form of naturalistic inquiry (Lincoln \& Guba 1985:14-46) is employed, since it enables the researcher to engage at a holographic level - as anything larger may be impossible to render. Delphi is best suited to researching, at a meta-theoretical level, the causation of decline and possible remediation for the Canadian Evangelical Church because it is 'a method for structuring a group communication process so that the process is effective in allowing a group of individuals, as a whole, to deal with a complex problem' (Linstone \& Turoff 2002:3).

In the case of the Evangelical Church in Canada complexity intersects at many different levels. There is the complexity that arises from the Evangelical Church's very nature as an organism (Minear 2004:173-220). As an organism, there are many external and internal factors that act upon the church. Those factors are shaped or impacted in turn by the church as a respondent, non-static agent. This notion of the church as an organism, a living system, affects any perception of linear causality versus mutual causality (Lincoln \& Guba 1985:54; Oden 2006:283). In investigating the decline of the Evangelical Church in Canada the researcher may need to remain alert to the many external (macro-environmental or societal) factors as well as the internal (people dynamic) factors and the interrelated concept of mutual (macro- and internal) interaction. This conception of mutual interaction and mutual causation or shaping is a foundational premise of Bibby's book, Restless Churches (2004) - although he may not conceive of it as such. Bibby has picked up on the mutual intersection of the change in society and the impact of this change on the church. He is also acutely aware that the changes the macro-context (change in society) has wrought on the church is, in fact, part of the reason the church now interacts negatively with society and is thus losing ground (Bibby 2004:85-119). It is very helpful, when thinking through the concept of mutual causation and complexity, to engage some of the literature that defines, describes and distils the notion of complexity (such as Gell-Mann 1994) - especially as complexity relates to mutual causation and complex organisms, i.e. complex adaptive systems (Gribbin 2004:110 144). The Evangelical Church in Canada experiences many complex aspects of mutual causation. This mutual causation process is diagrammed in Figure 1.

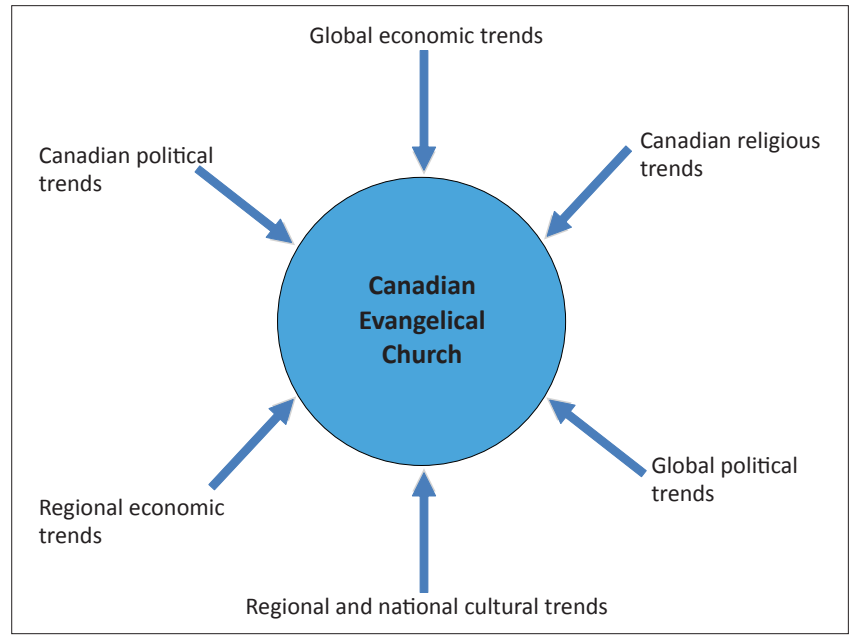

FIGURE 1: Canadian Evangelical Church as a complex adaptive system.

\section{The church as a complex adaptive system}

It is appropriate at this juncture to expand on the notion of the local church as a complex adaptive system. The conception of the church as a complex adaptive system is a way of viewing the Evangelical Church as comprised of many different and distinctive but interacting elements (1 Cor 12; Eph 4:17). If one thinks of the Christian church in the world today, there are many different churches that comprise this global entity of the church. These churches each in turn exist in particular contexts with particular cultural variations that impact how each particular church views itself and in turn structures itself and then relates to the world and to other churches from within that structure. Within each church there is the further complexity of families and individuals, each with their own world-view and with their own particular spiritual gift or gifts. The result is that there is a complex pattern (Gell-Mann 1994:30) of communication and mutual interaction between the various components of the system or living organism known as the 'church'. In its fullest sense the church is 'the community of all true believers for all time' (Grudem 2000:853). Grudem (2000:855-856) argues that there is both an invisible and a visible aspect to the church. Grudem (2000) defines the visible church in this way:

The visible church is the church as Christians on earth see it. In this sense the visible church includes all who profess faith in Christ and give evidence of that faith in their lives. (p. 856)

The visible church as defined by Grudem (2000:853-858) is, by its very nature, a complex system because it comprises many different people from many different cultural backgrounds who profess faith in Christ. Another way of understanding the visible-invisible distinction of the church is Grudem's (2000) definition of the church as 'local and universal'. Grudem makes the distinction thus:

In the New Testament the word 'church' may be applied to a group of believers at any level, ranging from a very small meeting in a private home all the way to the group of all true believers in the universal church. (p. 857)

Within a complex adaptive system apparently complex behaviours emerge 'as a result of often nonlinear spatio- 
temporal interactions among the larger number of component systems at different levels of organization' (Chan 2001:1). This notion of the church as a complex adaptive system is extremely helpful when reflecting on the decline of the Evangelical church in Canada for two reasons. Firstly, according to Grudem's definition of the local and universal church, the church of the Lord Jesus is much larger than the church in any single country or context. This means that even if the church in Canada declines, or even ceases to exist, the promise of the Lord Jesus in Matthew 16:17-20 still holds true. The one aspect that is hard to measure is the degree to which the interrelatedness of the components of the system will impact the global church. Health or decline in one part of the system should impact the rest of the system. At a more micro-cosmic level, each member of a local church impacts every other member of a local church in a positive or negative way - this is the nature (Chan 2001:1) of a complex system. According to many passages in the New Testament (e.g. Eph 4:15-16; 1 Cor 12; Phlp 1), the church is a complex adaptive system comprised of many distinctive elements that are interconnected. As Chan (2001:1) points out: 'Complexity results from the inter-relationship, interaction and inter-connectivity of elements within a system and between a system and its environment'. The internal and external dynamics and the inter-action and inter-connectivity of these dynamics within the Canadian Evangelical Church and between the Canadian Evangelical churches and their environment are reflected in the responses to the Delphi survey that follow. It is extremely helpful to understand that the Evangelical Church may be in a decline because of systemic inter-relationships, both internally and externally. The tension of the impact of these inter-relationships is clearly expressed in the responses of the Delphi experts, to which we turn our attention in later sections.

\section{Movement from mechanical to holographic images}

The concept of movement from mechanical to holographic images was first propounded by Schwartz and Ogilvie (1979:13-14) and was later developed and expanded by Lincoln and Guba (1985:52-53). It was used more recently by Oden (2006:283) to describe the nature of the Catholic Church. The concept is extremely helpful when attempting to understand an entity which is highly complex by nature, such as the Evangelical Church in Canada. The core tenet (Lincoln \& Guba 1985:53; Oden 2006:283) of this aspect of naturalistic inquiry and movement from mechanical to holographic images is that it supports the process of an iterative survey of experts to gain an understanding of a small piece of the whole - since one can never hope to review the expansive whole, which is almost infinite in its complexity with contributing and mutually affecting factors and outcomes. In regard to the challenge of researching such complexity within the field of practical theology, Osmer (2010) states the following:

Moreover, the expansion of global telecommunication, migration, law, and capitalism have eroded local traditions, evoked fundamentalist reactions, and made encounters with cultural 'others' a part of our everyday life. If reflective practice in the context of modernity could still assume fading Christendom, it can no longer do so today. Church leaders cannot even assume that a program working well in one congregation will work in a similar congregation in another part of their own country. Indeed, they cannot even assume that a program that is appealing to middle-aged and older adults will appeal to youth and young adults who belong to the same congregation ... If reflective practice was important in the context of modernity, it has become doubly so in a post-Christendom, postmodern, globalizing world. In this context, the practical theological paradigm of reflective practice has a great deal of plausibility. (n.p.)

In the current context of post-modern, post-positivist complexity, no single church, or even group of churches, can be set apart for selection, since in the current context a large sampling is needed with a view to identifying some broad macro-trends that in turn might have generic applicability to the Canadian Evangelical Church as a monolith, and by extension to the Canadian Evangelical churches that form a part of that monolith.

It is here, on the broad macro-trend level, that a holographic (Oden 2006:283) rather than a mechanical image approach might be useful (Lincoln \& Guba 1985) because:

It turns out that holographs have an unusual property. If a normal recording or a normal film were damaged in some way - for instance, through the loss of some portion of the whole - then that same portion of the whole would be lost. But holographs have the property that, even if large portions of the recorded interference patterns are lost, the remaining pieces, no matter how tiny, will all have complete information and will be able to reproduce the original image in its entirety (and in three dimensions!). Every piece of a system has complete information about the whole. (p. 53)

This concept of the power of holography to contain all dimensions of a whole image in a small fragment is an extremely powerful metaphor that is helpful in framing the research process as it relates to the Delphi method of inquiry. The Delphi method surveys experts in a series of iterative refinements to obtain consensus on a complex issue under review - a holographic snapshot as it were of the larger, more complex whole. It seems that, currently, with greater research and further scientific development of holographic technology, this holographic metaphor is now highly plausible (Bowen 2009; Jain \& Sharma 2005). In essence, since we are not able to gain an exhaustive reading on the causes for the decline of the Evangelical church from a merely quantitative study (statistics do not speak to causation - only actuation), and the mutual causations seem to be varied, widespread and very complex, we need a different research method and research model that can take all of these variables into account. We require, for this research, a model that can take a snapshot of the whole and then through that snapshot portray a projected image of the whole. This is the holographic metaphor as expressed in the Delphi method: the Delphi takes a snapshot through an analysis and synthesis of a cycle of iterative questionnaires that build consensus and move with the experts to a synthesised and common conclusion. This movement is neither contrived nor forced; it is a natural outflow of the impact of the anonymous responses of one 
expert upon another until there is a nub of consensus, or data satisfaction. The Delphi does not render quantitative facts about the topic under research. However, the Delphi does render the combined submissions or perspectives of the experts who are practitioners that are interacting with the topic of research in meaningful and substantive ways and thus have a grasp or sense of the topic that is both helpful and enlightening. The following sections detail the history of the Delphi method, the ways in which the Delphi method can and has been applied and how the Delphi method was used in this particular study.

\section{The history of the Delphi method}

The foundation of the temple at Delphi and its oracle is a mythical tale and is purported to have taken place before recorded history. For at least a thousand years of recorded history the Greeks and other people, sometimes as private individuals, sometimes as ambassadors, came to Delphi to consult the prophetess, who was known as Pythia. It was believed that Pythia's words revealed the rules of the Gods (Cuhls 2009).

The original Delphi method was developed in the 1950s by the Rand Corporation's Norman Dalkey (Linstone \& Turoff 2002:10; Skumolski et al. 2007:2). According to Skumolski et al. (2007), the goal of the original Delphi project was:

... to solicit expert opinion to the selection, from the point of view of a Soviet strategic planner, of an optimal U.S. industrial target system and to the estimation of the number of A-bombs required to reduce the munitions output by a prescribed amount. (p. 2)

Put more simply, the goal of the original study was 'to obtain the most reliable consensus of opinion of a group of experts ... by a series of intensive questionnaires interspersed with controlled opinion feedback' (Linstone \& Turoff 2002:10). This first Delphi survey was used to answer this critical question of Soviet munitions output because there were so many subjective elements involved in the research process, and the cost of any alternative form of research would have been immense. Added to these factors was the reality that there was no extant accurate information or data concerning the topic under research (Linstone \& Turoff 2002:10). After this initial defence application of the Delphi technique a philosophical paper on the Lockean type Delphi created impetus for a number of individuals to begin experimentation with Delphi in non-defence areas (Linstone \& Turoff 2002:11).

After the initial Rand study the Delphi method of research expanded and diversified, as Cuhls (2009) states:

Shortly after the Rand study of the 1950s and further individual studies through the 1960s, the development and broader application of the Delphi method was taken over by Japan. Although the first large Delphi study in Japan did not correctly describe the oil price shock and was conducted and published just before that happened, the Japanese Delphi process continues every five years. It is regarded as an update of data concerning the future. With the resurrection of foresight in general and the possibilities to filter all these 'options' of different actors, the Delphi technique was taken out of the toolbox and implemented in Europe in a different manner than in the early years. In the new wave of large-scale government foresight in Europe, Dutch and German government agencies and similar bodies were among the first, with France and the United Kingdom joining in quickly. (n.p.)

\section{Definition of the Delphi method}

There are a number of definitions that pertain to the Delphi method. Each of these suggests a different insight into the nature and use of the Delphi method. Skumolski et al. (2007:1) define the Delphi method as 'an iterative process to collect and distill the anonymous judgments of experts using a series of data collection and analysis techniques interspersed with feedback'. According to them, the strength and focus of the Delphi method as a research process is that it 'is well suited ... when there is incomplete knowledge about a problem or phenomenon; however it is not a method for all types of IS research questions'. Linstone and Turoff (2002:3) define Delphi as 'a method for structuring a group communication process so that the process is effective in allowing a group of individuals, as a whole, to deal with a complex problem'. Much in line with the previous two definitions but expanding upon them is the definition provided by Hsu and Sandford (2007):

The Delphi technique is a widely used and accepted method for gathering data from respondents within their domain of expertise. The technique is designed as a group communication process which aims to achieve a convergence of opinion on a real-world issue. (p. 1)

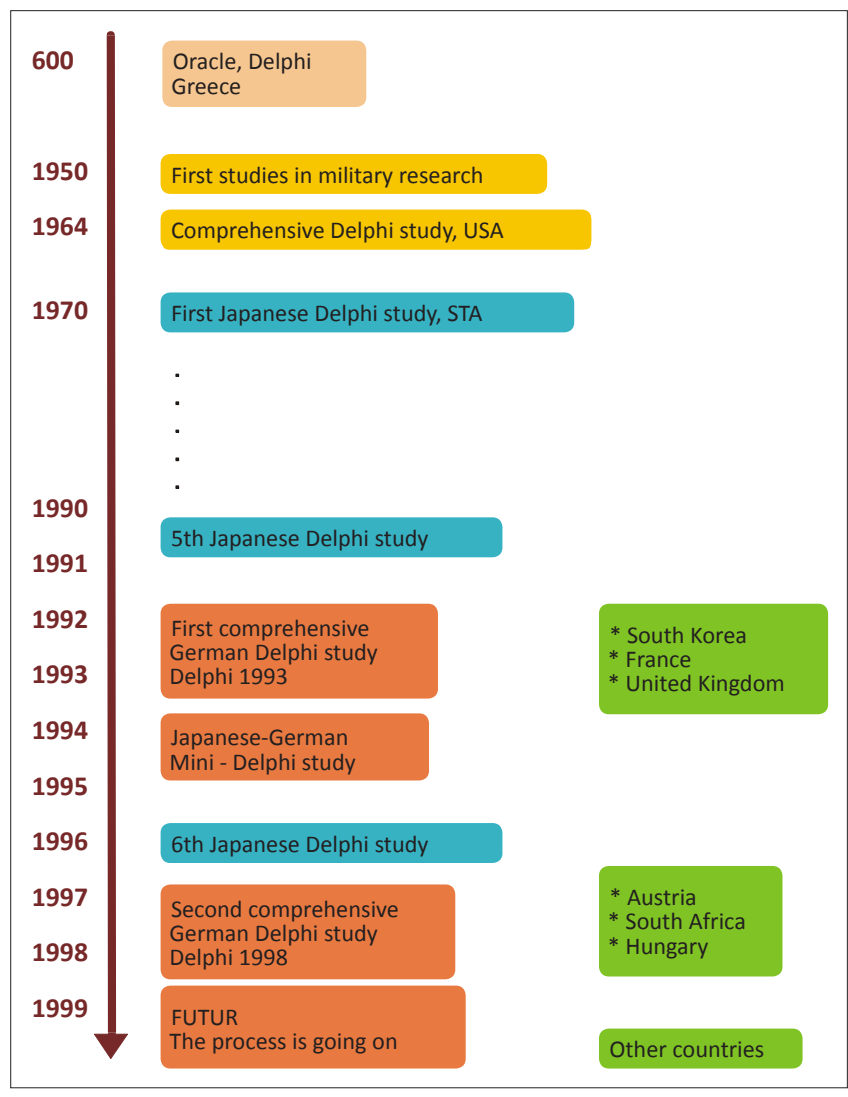

Source: Cuhls, K., 2009, Delphi method, viewed 01 November 2010, from http://www.unido. org/fileadmin/import/16959_DelphiMethod.pdf

FIGURE 2: Genealogical tree of Delphi. 
These are all helpful definitions, although we prefer the definition by Skumolski et al. (2007:1). This definition highlights the strength of Delphi 'when there is incomplete knowledge about a problem or phenomenon', such as exists with the complex issue of the decline of Evangelical churches in Canada, regarding which a literature review surveying the nature of and the reasons for the decline rendered very sparse results. Currently, the reasons for the decline of the Evangelical churches seem not altogether clear, and these reasons have not been widely researched. The definition by Skulmoski et al. supports the use of the Delphi survey within the current Canadian milieu since the experts who complete the Delphi survey are practitioners who are grappling with the possible reasons for the decline and the possible ways forward.

\section{The various types of Delphi survey}

There are five different types of Delphi survey (Mitroff \& Turoff 2002:18-34). Each of these different types of Delphi method encompasses a different philosophical mode or system. The five different Delphi methodologies or inquiring systems are listed below together with the characteristic question each of these inquiring systems would ask to accept the research propositions as valid or true:

1. The Leibnizian method: 'How can one independently of any empirical or personal considerations give a purely rational justification of the proposed proposition or assertion? Can one build or demonstrate a rational model which underlies the proposition or assertion? How was the result deduced; is it precise, certain?'

2. The Lockean method: 'Since for me data are always prior to the development of formal theory, how can one independently of any formal model justify the assertion by means of some objective data or the consensus of some group of expert judges that bears on the subject matter of the assertions? What are the supporting "statistics"? What is the "probability" that one is right? Are the assertions a good "estimate" of the true empirical state of affairs?'

3. The Kantian method: 'Since data and theory (models) always exist side by side, does there exist some combination of data or expert judgment plus underlying theoretical justification for the data that would justify the propositions? What alternative sets of propositions exist and which best satisfy my objectives and offer the strongest combination of data plus model?'

4. The Hegelian (Dialectical) method: 'Since every set of propositions is a reflection of a more general theory or plan about the nature of the world as a whole system, i.e., a world-view, does there exists some sharply differing world-view that would permit the serious consideration of a completely opposite set of propositions? Why is the opposing view not true or more desirable? Further, does this conflict between the plan and the counterplan allow a third plan or world-view to emerge that is a creative synthesis of the original plan and counterplan?'

5. The Singerian method: 'Have we taken a broad enough perspective of the basic problem? Have we from the very beginning asked the right question? Have we focused on the right objectives? To what extent are the questions and model of each inquirer a reflection of the unique personality of each inquirer as much as they are felt to be a "natural" characteristic or property of the "real" world?'

The Delphi method used for the research presented in this article is the Lockean inquiring system (IS) (Mitroff \& Turoff 2002:20-22). The Lockean IS was chosen because it presents the following core components that contribute to researching the complex question of the decline of the Evangelical Church in Canada and possible models to address this decline.

- Truth is experiential, that is, the truth content of a system (or communication) is associated entirely with its empirical content. A model of a system is an empirical model and the truth of the model is measured in terms of our ability to reduce every complex proposition down to its simple empirical referents (i.e. simple observations) and to ensure the validity of each of the simple referents by means of the widespread, freely obtained agreement between different human observers.

- A corollary to the above is that the truth of the model does not rest upon any theoretical considerations, i.e. upon the prior assumption of any theory (this is the equivalent of Locke's tabula rasa). The only general propositions which are accepted are those that can be justified through 'direct observation' or have been justified previously through direct observation.

In brief, Lockean ISs are the epitome of experimental, consensual systems. On any problem they will build an empirical, inductive representation of it. They start from a set of elementary empirical judgements ('raw data', observations, sensations) and from these build up a network of ever expanding, increasingly more general networks of factual propositions. A typical Lockean point of view is the assertion that one does not need any theory in order to collect data first, only to analyse it subsequently (Linstone \& Turoff 2002:20).

Since there was a very small body of academic literature related to the decline of the Evangelical churches in Canada, the Lockean IS presented the best Delphi method for the research project outlined in this article. Each of the questions, especially those that were developed in the first iteration, was developed with a tabula rasa approach. For this reason the questions were framed with a strong component of opinionbased thinking, for example: 'I believe that the Evangelical Church in Canada is facing the following challenges to its health at this time'; 'I believe that the Evangelical Church in Canada would grow in size and/or effectiveness if ...' and 'The Evangelical Church needs to address the following areas of church life if it hopes to thrive and in turn to impact the Canadian population with the Gospel'. These questions are indicative of the tabula rasa approach that informs and underlies the Lockean Delphi method - there is no predisposing theory either assumed or presented; rather, it is hoped that the data will develop the theory as the data is analysed and synthesised into a second and third iteration. The strength of this Lockean approach for this particular research is its: 
... ability to sweep in rich sources of experiential data. In general, the sources are so rich that they literally overwhelm the current analytical capabilities of most Leibnizian (analytical) systems. The weaknesses, on the other hand, are those that beset all empirical systems. While experience is undoubtedly rich, it can also be extremely fallible and misleading. (Mitroff \& Turoff 2002:22)

Senge (2006:23) alludes to the same pitfalls of learning from experience when it comes to systems theory, but in this instance it was felt that the data yield from the opinions expressed by the experts, even though driven by personal experience and personal world-view, would assist in creating an understanding of why practitioners feel that the Evangelical churches across Canada are in decline. Whether or not their perceptions are accurate or not, they still create a theory that can be evaluated and tested against other mechanisms, such as similar research in other Western countries, to provide a refined and workable theory that is set against the backdrop of the outcomes of the Delphi survey.

Since this Delphi survey asks experts to relay their perceptions of the factors that have led to or are currently contributing to the decline of the Evangelical Church, their responses could be perceived as 'pooled ignorance'. This perception might arise because, though immersed in the task every day and reflecting on the task both intuitively and academically, the experts are answering from the basis of their own experience, perception and world-view. This potential weakness can be overcome by synthesising the opinions of the experts into a set of commonly identified and expressed contributory factors. If each of the experts is identifying and expressing the same or similar answers concerning what they perceive to be the cause of the problem, then at very least we have a measure of causation - whether real or perceived. The key then lies in the capacity to reflect on and attempt to analyse the responses given - always with a systems perspective in mind as opposed to a mere symptomatic perspective. As an example, one of the key concerns that emerged in the initial survey is that of the perceived 'lack' of expository preaching and its link to the decline of the Evangelical Church in Canada. It was most helpful that because of the nature of the Delphi process one of the respondents had opportunity in the second iteration to challenge this perception as a catchall - since the respondent asserted that he in fact is preaching expository sermons, as are many other practitioners that he personally knows. The problem is not with the perception or with the data - how would one survey the hundreds of thousands of Christians across Canada to determine if their particular minister is in fact preaching expository sermons, or if they even perceive the sermons to be expository? Perhaps the challenge is not in the perception or even in the accuracy of the perception - but the subtle systemic equation that underlies the perception: 'We see a high level of carnality and apathy within the Canadian Evangelical churches together with a very low biblical literacy - this must be a result of a lack of expository preaching!' There are so many more factors that might impact a congregant and pressure that individual to experience a low biblical literacy and apathy in his or her own spiritual disciplines and walk with the Lord. Expository preaching is never done in a vacuum and thus it would seem that there could be many diverse factors contributing to the sanctification and growth of a Christian, or the lack of growth in the life of a Christian. If expository preaching were all that was needed to grow the modern Christian to a place of maturity, it could be argued that the Canadian Evangelical Christians should be the most mature on the planet, because of the availability on the Internet of so much expository preaching in digital format. This brief detour illustrates some of the challenges of working with a Lockean Delphi method. However, even with this awareness it is still a very helpful research tool in examining the factors that contribute to the decline of the Evangelical Church in Canada and a possible model to address this decline.

\section{The use of the Delphi method in practical theological research}

In this section we discuss how the Delphi method was used as a tool for gathering data from experts in the field of Evangelical Church ministry in Canada. The Lockean IS informed a series of on-line surveys that were constructed in an iteratively developmental process. Each successive survey distils and builds upon the previous survey, as prescribed by the Delphi methodology. The synthesis of each progressive survey is provided for the reader in the sections below. The selection of experts was based on the four criteria for experts suggested by Skumolski et al. (2007:4). These four criteria are:

- knowledge and experience with the issues under investigation

- capacity and willingness to participate

- sufficient time to participate in the Delphi

- effective communication skills.

These four criteria led to the selection of a range of lead pastors across Canada who had been in ministry for at least five years (even if their tenure at their current church ministry was less than five years).

\section{First Delphi iteration: The formative questionnaire}

The first questionnaire was developed to build a profile of the experts who would be responding and to set a baseline for the data being gathered. Since Delphi respondents do so anonymously, it is helpful to know a bit of their background, both in terms of experience in the field under review and in terms of their level of formal research into the field under review. To fulfil the requirements of a Delphi survey, all responses were submitted anonymously. This means that, whilst the respondents are known, it is not known which of the eight response sets submitted belongs to a particular respondent. The fact that the respondents all came from different theological, educational, age and denominational backgrounds gave this particular Delphi survey strength. However, all respondents have a common interest in and commitment to the Evangelical Church in Canada. 


\section{Vocational profile}

Three of the eight respondents fill the role of lead pastor in a local church. Three respondents serve as leader (regional director, president) of their respective Evangelical denomination. Another three respondents are academics involved in research related to the Evangelical Church in Canada. There is an anomaly in the tally of responses since there are nine vocations listed although there are only eight respondents. It seems plausible to infer that one of the respondents holds two vocational positions, that is, lead pastor and academic, or lead pastor and denominational leader.

\section{Academic profile}

As outlined in Table 1, there was also great diversity in the academic profile of the respondents. One respondent holds a non-theological doctoral degree and four of the respondents hold a master's degree in a theological discipline. Two of the respondents hold a non-theological undergraduate degree, whilst three of the respondents hold undergraduate theological degrees. One respondent has a high school certificate as highest qualification. Another anomaly surfaced in that there are 11 educational levels represented by eight respondents. To resolve this anomaly it may be helpful to consider that four of the five undergraduate degrees went on to further study at master's level and one respondent pursued non-theological study at doctoral level. Table 1 may help clarify this anomaly further as one possible permutation of the academic profile of the respondents.

\section{Denominational profile}

Presbyterians, Wesleyans, Baptists and Pentecostals formed the denominational profile of the eight respondents.

The fact that there is denominational diversity strengthens the integrity of the Delphi survey as it highlights the fact that the challenges to the growth of the Canadian Evangelical Church are experienced across a range of denominational perspectives. The implication is that there is no single practice or even doctrinal persuasion that is hindering the growth of any particular denomination within Canada. Rather the challenges being faced are germane to a broad cross-section of the Evangelical Church in Canada.

\section{Age range profile}

The Delphi survey also incorporated a broad age spectrum in the first iteration of the survey. The youngest respondent

\begin{tabular}{lllll}
\multicolumn{2}{l}{ TABLE 1: Academic profile of respondents. } \\
\hline High school & $\begin{array}{l}\text { Undergraduate } \\
\text { non-Theology }\end{array}$ & $\begin{array}{l}\text { Undergraduate } \\
\text { Theology }\end{array}$ & $\begin{array}{l}\text { Master's } \\
\text { Theology }\end{array}$ & $\begin{array}{l}\text { Doctoral } \\
\text { non-Theology }\end{array}$ \\
\hline 1 & - & - & - & - \\
- & 1 & - & 1 & - \\
- & 1 & - & 1 & - \\
- & - & 1 & - & - \\
- & - & 1 & - & - \\
- & - & 1 & 1 & - \\
- & - & - & - & 1 \\
- & - & - & 1 & - \\
\hline
\end{tabular}

was 38 years of age and the oldest was 69 years of age. The other ages indicated were 39, 46, 52 and 63. The diversity of age did not diminish the common expression of awareness that the Evangelical Church in Canada is facing difficulty in the 21st century.

\section{Theological profile}

A broad range of theological categories were provided by respondents (the number of respondents for that particular theological category is placed in brackets): Conservative (0), Fundamentalist (0), Progressive (0), Traditional (2), Evangelical (4), Reformed (1), Emergent (1), Liberal (0). It is interesting that every respondent attached some theological label to himself or herself, even though the labels were not clearly defined. None of the respondents placed themselves at either end of the scale as Conservative, Fundamentalist or Liberal. Again, the diversity of the theological profile, albeit slight and nuanced, serves to strengthen the integrity of the Delphi data because the respondents all agree that the Canadian Evangelical Church is facing real challenges in the 21st century context.

\section{Length of current ministry profile}

There was also diversity in the length of current tenure as reported by the eight respondents to the first iteration of the Delphi survey. The shortest tenure at the time of the survey was two years in the current ministry position (as lead or senior pastor). The longest tenure at the time of the survey was fourteen years. The range of tenure in their current position started at two years, then six years, eight years, twelve years, thirteen years, and finally fourteen years.

\section{Results of the first iteration of the Delphi survey}

The Delphi survey, in its fullness, is a compilation of a series of at least two or more iterations. The key to the effectiveness of the Delphi method is a process of obtaining the data from expert respondents, placing the various responses side by side, analysing the responses and then, after attempting a synthesis of the responses, creating a new questionnaire. The new questionnaire attempts to reflect the synthesis of the responses and then attempts to refine and clarify the data rendered through a series of further questionnaires, each of which follows the same cycle of analysis, synthesis and further probing until a form of 'consensus' by the experts is reached. In this case, the goal of this consensus is to gain a clearer picture on how the experts view the suggested challenges now facing the Evangelical Church in Canada. Do the experts think we have a problem, are they able to identify and articulate the various components of this problem, and do they suggest possible plausible solutions?

Conducting a Delphi survey is akin to dynamic exposure, in real time, of the thoughts of an author before that author has even captured those thoughts on paper or had time to research the validity of those thoughts as they emerge. This type of research fits well within the naturalistic paradigm espoused 
by Schwartz and Ogilvie (1979:13-14) and expanded upon by Lincoln and Guba (1985:47-69), especially the notions of 'movement from mechanical to holographic images' (1985:52), and movement from 'objective to perspectival views' (1985:55). These concepts were explained in greater detail in an earlier section; they are repeated here to highlight the processes undertaken in the following sections and the rationale for those processes as an attempt to analyse and synthesise the data supplied by the eight respondents to the Delphi survey.

The responses listed below are those provided by the eight respondents. Not every response is given; rather the question is stated and then a synthesis and analysis of the eight responses to the question is given. Other respondents repeated some responses; some responses were unique to one particular respondent. The goal of the Delphi method is to synthesise the responses into a platform for a second questionnaire that will further focus the respondents and refine their responses, especially once they have a sense of other respondents' responses to the same questions.

\section{Question: I believe the Evangelical Church in Canada is facing the following challenges to its health at this time}

1. There is a declining biblical literacy and a widespread declining knowledge of the major tenets of the Christian faith. The platform for presenting the Gospel has been eroded because there is no longer a 'Christian' or 'biblical' pre-understanding of the message.

2. There is a desire for a customised and individualised spirituality. This erodes community and common mission because there is no central doctrinal authority as a reference point to 'norm' the community.

3. There is, within Evangelical churches, a lack of strategic planning and implementation. This is tied to the fact that the church leadership is insecure and continuously looking for the latest thing that works rather than developing a strategic plan that employs the giftedness of the believers within the church to meet the needs of that particular church and community.

4. There is a lack of equipped leaders, a lack of training for leaders and a lack of good methods for training leaders within churches.

5. There is a weakness in terms of Bible preaching and, tied to this, a lack of Bible preaching that relates to reallife issues. Biblical preaching is replaced by therapeutic, moralistic deism.

6. There is a sense, tied to response (5) above, that there is a lack of connection between the ministry of Evangelical churches and real-life struggles. The Evangelical Church has become a moralist without compassion for those who are trapped in sin. Instead of developing a theology of engagement, which enables the church to become a redemptive and missional community, the Evangelical Church seems to have withdrawn with a longing for the (Christianised?) past. The Evangelical Church is not living and acting by faith.
7. There is, within the Evangelical Church, a lack of corporate prayer.

8. There is, within the Evangelical Church in Canada, a lack of commitment from the members and adherents.

9. Materialism pervades and weakens the ministry capacity of the Evangelical Church in Canada. Resources abound to do the work, but a lack of commitment and a materialistic world-view hinder the ability of the churches to deploy the latent resources within.

10. 1Syncretism permeates and weakens the Evangelical Church in Canada. We have become indistinguishable from the community at large and so we have nothing to offer. We need to return to living out the Kingdom ethic in our fallen world by the power of the Holy Spirit for the Glory of God.

11. The Evangelical Church needs to become more involved in incarnational evangelism - as children of God living out the ethics of the Kingdom and thereby touching broken lives in profound ways to lead them to the saving grace of a living and holy God who sent His only Son as the perfect sacrifice for sin.

12. The Evangelical Church needs to provide a mechanism for Christians to grow and experience transformative life change into Christ-likeness.

\section{Question: The Evangelical Church needs to address the following areas of church life if it hopes to thrive and impact the Canadian population with the Gospel}

1. Return to biblical and expository preaching that intersects the real issues of life.

2. Return to daily practice of the spiritual disciplines of prayer, meditation, Bible reading and sacramental living.

3. Return to the church as community, which means larger time investments by those who are the church to actually be the church.

4. Return to visionary leadership that develops a sustainable strategic plan that utilises the giftedness of those within the church to meet the needs of the church body and the community at large.

5. Return to the individual priesthood of the believer as gifted by God to minister to the community of God and to serve together with other believers as part of the missional community of God.

\section{Question: I think that the Canadian Evangelical Church has been affected by the following cultural or macro-environmental trends}

1. The de-Christianisation of Canada and Western culture.

2. The influx into Canada of immigrants with differing religious backgrounds and perspectives.

3. Pervasive consumerism and materialism that absorb people's focus and priorities.

4. A post-modern world-view that presents truth as relative and subjective.

5. The powerful silencer of political correctness that puts immense pressure on Christians to minimise important truths for the sake of tolerance. 
6. Militant feminism and a consequent redefinition of all gender roles across society in Canada.

\section{Question: I believe that the type of leadership needed to bring health and growth to Evangelical Churches across Canada is leadership that is characterised by:}

1. Compassion blended with mission, vision, passion, intention and action.

2. The courage to speak biblical truths even when these may seem to contradict the traditional Evangelical metanarrative.

3. Leadership that is servant focused - not leadership focused in a narcissistic way.

4. Leadership that is spiritually vibrant, disciplined, humble and enduring.

5. Leadership that is willing to suffer ignominy, financial loss, humiliation and weakness.

6. Leadership that is communally focused rather than individualistically narcissistic, that is interconnected and interdependent.

\section{Analysis of the responses to the first iteration of the Delphi survey}

The eight respondents to the first iteration of the Delphi survey displayed a remarkable grasp of the micro, macro, internal and external trends that they perceive to be wracking the soul of the Evangelical Church in Canada at this time. There is a remarkable synergy between their answers and an authentic transparency that these trends are pervasive not only within Canadian society, not only within the Canadian Evangelical Church, but also within the leadership of the Canadian Evangelical Church, of which they form a part. Such authenticity and self-awareness reflects, it would seem, the reality that these respondents have been reflecting on this issue for some time and that they have been trying to frame the decline in ways that make sense to them.

As one reads through the responses of these eight experts, one is struck by the sense that these leaders perceive that the Evangelical Church in Canada has been invaded by pervasive cultural trends and is now reeling under the weight of these trends, which actually become threats to its very existence. These experts understand that the church is a complex adaptive system and that it is not immune to the social forces that surround and infiltrate the church through the world-views of those who form part of the church. These leaders are courageous in their diagnosis of the problem and in their concept of the prescription. They are also aware of the complexity of the issues before them. The respondents propose a remedy that is at once profound yet simple, impossible yet realistic. In short - they propose what they perceive to be a return to biblical Christianity in a post-Christian world. This proposal is extremely helpful in constructing a possible model for the growth of the Evangelical Church in Canada. However, the next iteration of questions in the Delphi survey will attempt to crystallise how exactly respondents feel such a return to biblical Christianity might occur in tangible ways. As an example of how the next iteration of questions might crystallise and clarify the methodology or praxis of biblical Christianity in 21st-century Canada, consider the following examples from the synthesis of the responses above:

1. Return to biblical and expository preaching that intersects the real issues of life.

- Question: How can pastors structure their church ministry in such a way that they can ensure they spend the time needed to develop effective expositional preaching that truly represents the authorial intent of the Holy Spirit with life changing application to the issues of Canada in the 21st century?

- Question: How can Evangelical churches, Bible colleges and seminaries partner together to ensure that a new cadre of leaders who are biblical expositors is produced?

- Question: What are the hindrances to biblical expository preaching in 21st-century Canada?

The full expression of this second iteration of questions and the responses of the experts to these questions are recorded in the next section.

\section{The second iteration of the Delphi survey}

The objective of the second round of the Delphi survey was to synthesise and refine the responses from the first Delphi iteration. To fulfil the requirements of the Delphi method 'the validity of the resulting judgment of the entire group is typically measured in terms of explicit degree of consensus among the experts' (Linstone \& Turoff 2002:22). The results of the second Delphi survey display a measure of refinement. However, the reader will observe that some questions arose from the respondents concerning the validity of some of the responses to the first Delphi questionnaire - especially concerning the idea that part of the current decline can be attributed to a decline in 'expository preaching'. Where such disparities emerge they are highlighted for the reader and discussed. However, such disparities do not undermine the validity of the Delphi method but actually support it. As Linstone and Turoff point out (2002):

What distinguishes the Delphi from an ordinary polling procedure is the feedback of the information gathered from the group and the opportunity of the individuals to modify or refine their judgments based upon their reaction to the collective views of the group. (p. 22)

The reader will observe that the modification and refinement of views occurred naturally in the second iteration of the Delphi survey. Whilst this process of refinement and modification is both helpful and validating in terms of the Delphi survey as a research tool into the possible causes for decline in the Canadian Evangelical Church, two caveats remain:

1. 'While experience is undoubtedly rich, it can also be extremely fallible and misleading' (Linstone \& Turoff 2002:22). 
2. 'The judgments that typically survive a Delphi procedure may not be the "best" judgments but, rather, the compromise position' (Linstone \& Turoff 2002:22).

The responses to the second iteration of the Delphi survey are presented below. The two caveats mentioned above serve as a filter to the responses and the comments on those responses. Another important notation regarding the second iteration of the Delphi survey is that only five of the original eight experts responded. The reason for this attrition is hard to ascertain - other than the possibility that some of the previous respondents may have lost sight of the value of the Delphi - since it is purely voluntary and there is no remuneration for the time expended. One other factor in the attrition of respondents might be that some of the respondents felt that they had expressed their opinions and did not see the value in refining those opinions based upon what others might be saying. It seems, though, that since the process was completely voluntary, and time is at a premium for church leaders, attrition should be expected.

\section{Declining biblical literacy}

The previous Delphi survey discovered concern over declining biblical literacy and knowledge of the major tenets of the Christian faith. How would you suggest the Evangelical Church in Canada address this decline?

1. Faith in the home initiatives.

2. Expository preaching and Bible studies.

3. Holistic integrated living in community.

4. A catechism of theology for children.

5. Elevate Grade 1-8 'Sunday school' programmes from being an afterthought to being a core, highly resourced ministry.

6. A return to active Christian education in the church for all ages: children, youth and adults. Revitalise Sunday school.

7. Return to biblical preaching.

8. Revive the concept of church-based theological training.

\section{Individualised spirituality}

There is a strong trend in Canada towards individualised and customised spirituality. How can the Evangelical Church in Canada address this trend? Can we use this trend to strengthen people in their discipleship? How do we help Christians to understand the need for and the benefit of Christian community?

1. NT teaching, expression of local church in oikos like social settings.

2. A strong sense that the 'individualised' approach or trend is not helpful. Community/others and service is lessened by the individualised approach.

3. The best way to strengthen communal commitment is through the community of small groups. Whilst it is good to strengthen the individual I also believe that, as Scripture says, 'iron sharpens iron'.

4. It begins with child and youth training. The sense is that a significant cause of 'individualised' spirituality is because the majority of twenty- and thirty-somethings have never learned the core doctrines together. They do not know why or what they believe, and certainly cannot be sure they believe the same thing as the person next to them, even though they grew up in church together.

5. Through biblical preaching and an emphasis on true Christian community.

\section{Lack of strategic planning}

Many in the previous survey lamented the lack of strategic planning and consistent, sustainable, enduring implementation of the planning within the life of the church. What mechanisms would you suggest to address this perceived need for strategic planning within Canadian Evangelical churches?

1. Strategic planning is part of the business model that has lost the life of the church as a Spirit movement of Jesus followers.

2. Pastors need to discuss this in their fraternals.

3. The idea that boards need a yearly retreat to reflect upon their mission and vision to make sure that all that they are doing is fulfilling their vision. Too often we are busy not being wise in spending the energy we do in effective ministry. So I feel we need a yearly evaluation and assessment as to whether the programmes we are carrying out or implementing are accomplishing our goal.

4. Increased inter-church projects. Less reinventing what others are already doing. Take a city-scale approach to the evangelical church to foster co-operation and by necessity each partner or participant will need to think bigger, longer term, more strategically in order to participate on a multi-church, city-wide scale.

5. Strong, elder-led congregations where accountability and vision is stimulated through shared leadership.

\section{Lack of equipped leaders}

Most respondents lamented the lack of trained and equipped leadership within the local church. What suggestions do you have to address this issue of a lack of trained leadership within the local church? How can local churches train and develop leaders to ensure that there is a broad base of godly leadership within any given local church?

1. One of the suggestions for effective equipping was the Rabbi model, in which peripatetic learning and real life mentorship occur in the place of curricular plans.

2. Encourage the members to attend less church services to free themselves up for more 'church service'. So much of what we do is 'in-house' and cognitive. We need to help them with 'hands-on', practical service in the community and train them to the presence of Christ, making the invisible God visible.

3. There are several things that can happen: Firstly, we have invited a person with a great deal of knowledge in leadership development to come and speak to us over a weekend. Secondly, we do leadership development for the first half hour at all our board meetings and lastly we 
find a seminar to which you can take your leaders (we have chosen Willow Creek Leadership Summit).

4. Just do it. Develop a leadership philosophy that says the church identify and mentor emerging leaders internally before posting a job advertisement for their next vacant staff position. Hiring from outside the church is rarely a good idea. It's a unique solution to a specific problem; it should not be the normal response to leadership needs. By establishing leadership training as the requirement for all spiritual leaders within the local congregation.

\section{Summary, synthesis and analysis of the responses to the second iteration of the Delphi survey}

In this second iteration of the Delphi survey, some clear and strong suggestions emerged from the respondents:

- Declining biblical literacy can be addressed through holistic integrated living that is informed by early childhood biblical literacy initiatives within the church and home, and by expository preaching for adult learning. The Delphi survey does not suggest how exactly these initiatives should be carried out; rather, it suggests that these may remedy the problem of declining biblical literacy, if they are implemented.

- Individualised spirituality can be addressed best by the New Testament teaching of the church as a family, a household of God as manifest in the expression of small group ministry within the larger church body. Canadian Christians need to move from autonomy to biblical interdependence.

- Lack of strategic planning was denigrated as a sign of a business model creeping into the church, at worst, or as something that needed to be fostered by joint collaboration of shared leadership, at best. It seems that some feel that a solid strategic plan provides a clear map to navigate the murky waters of a post-Christendom, post-modern secular milieu. Whether a well-designed and welldeveloped strategic plan could serve as a reliable map in such a context would need to be tested. The question whether or not strategic planning is antithetical to the work of the Holy Spirit requires evaluation.

- Lack of equipped leaders may be addressed best through mentorship, church-based theological and ministry training, and seminars. The mentorship process is certainly a valid proposition, although church leadership may need to have a long-term view of leadership development because of the lack of available Christian leadership, which means that mentorship initially will need to be done by existing leaders until a range of new leaders emerge from the mentoring process, who in turn can mentor other potential leaders. The notion of churchbased training would have to address the question of academic integrity and credibility.

- The majority of respondents refuted the idea of weakness in expository, biblical preaching as self-refuting and also as somewhat of a popular 'meme'. In the first iteration of the Delphi survey a lack of biblical preaching was presented as one of the areas that may have created weakness within the Canadian Evangelical Church. In the second iteration this proposition was undermined as untenable because each of the respondents felt that they were preaching biblical, expository sermons. They also felt that any of their colleagues would affirm that they too are preaching biblical, expository sermons. This response is important because it speaks to the perception of church leaders or practitioners that disconnection exists between the message being taught from the pulpits each Sunday and the lifestyles of believers across Canada.

\section{Conclusion}

The iterative Lockean Delphi method proved invaluable in gaining a clearer picture of the perceived encumbrances and pathologies that are hindering the Evangelical Church in Canada and the possible factors that are contributing to the decline of the Evangelical Church in Canada. As such, the Delphi method can serve as a valuable research tool to gain a snapshot of the current perceptions regarding and proposed solutions to a given problem in a specific area of research. Within the domain of practical theology the Delphi method serves the notion of reflective practice (Osmer 2010) well because it enables experts to reflect upon and articulate their opinions regarding issues that impact their praxis.

\section{Acknowledgements Competing interests}

The authors declare that they have no financial or personal relationship(s) which may have inappropriately influenced them in writing this article.

\section{Authors' contributions}

R.L.E (North-West University) designed and undertook the research in Canada, including the iterative survey process with the Delphi respondents. G.L. (North-West University) reviewed the research findings and suggested helpful refinements and also reviewed and refined the completed manuscript.

\section{References}

Bibby, R.W., 2004, Restless churches: How Canada's churches can contribute to the emerging religious renaissance, Novalis, Toronto, ON.

Borden, P.D., 2003, Hit the bullseye: How denominations can aim the congregation at the mission field, Abingdon Press, Nashville, TN.

Bowen, A., 2009, Holography - A different approach, viewed 25 September 2009 from http://www.docstoc.com/docs/5925759/how-do-3d-holograms-work

Chan, S., 2001, Complex adaptive systems: Research seminar in engineering systems, viewed 17 September 2010, from http://web.mit.edu/annakot/OldFiles/ MacData/afs.course/other/esd.83/OldFiles/www/notebook/Complex\%20 Adaptive\%20Systems.pdf

Cuhls, K., 2009, Delphi method, viewed 01 November 2010, from http://www.unido. org/fileadmin/import/16959_DelphiMethod.pdf

Gell-Mann, M., 1994, The quark and the jaguar: Adventures in the simple and the complex, Owl, New York, NY.

Gribbin, J., 2004, Deep simplicity: Bring order to chaos \& complexity, Random House, New York, NY. 
Grudem, W., 2000, Systematic theology, Inter Varsity Press, Leicester.

Hegazi, A.S., Hashish, A.H. \& Ahmed, E., 2009, On managing complex adaptive systems motivated by bio-systems application to infections, viewed 16 March 2011, from http://www.biomedcentral.com/content/pdf/1753-4631-3-11.pdf

Hsu, C.C. \& Sandford, B.A., 2007, The Delphi technique: Making sense of consensus, viewed 19 February 2011, from http://pareonline.net/pdf/v12n10.pdf

Jain, A. \& Sharma, T., 2005, A new dimension added to displays, viewed 25 September 2009, from http://bcognizance.iiita.ac.in/aug-sep05/technova2.htm

Kaiser, J.E., 2006, Winning on purpose: How to organize congregations to succeed in their mission, Abingdon Press, Nashville, TN.

Lincoln, Y.S. \& Guba, E.G., 1985, Naturalistic inquiry, Newbury Park, CA.

Linstone, H.A. \& Turoff, M., 2002, The Delphi method: Techniques and applications, viewed 16 March 2011, from http://is.njit.edu/pubs/delphibook

Lucas, C., 2006, Complex adaptive systems - Webs of delight, viewed 30 August 2005, from http://www.calresco.org/lucas/cas/htm
Minear, P.S., 2004, Images of the Church in the New Testament, John Knox Press, Louisville, KY.

Mitroff, I.I. \& Turoff, M., 2002, 'Philosophical and methodological foundations of Delphi', in H.A. Linstone \& M. Turoff (eds.), The Delphi method: Techniques and applications, e-Book, 618p. PMid:12190251

Oden, T.C., 2006, Systematic theology, Hendricksen, Peabody, MA.

Osmer, R.R., 2010, 'Practical theology: A current international perspective', paper presented at the Annual Conference for the Society for Practical Theology in South Africa, Pretoria, 2010.

Schwartz, P. \& Ogilvie, J., 1979, The emergent paradigm: Changing patterns of thought and belief, Report 7, Values and Lifestyles Program, SRI International, Menlo Park, CA.

Senge, P.M., 2006, The fifth discipline: The art \& practice of the learning organization, Doubleday, New York, NY.

Skumolski, G.J., Hartman, F.T. \& Krahn, J., 2007, 'The Delphi method for graduate research', Journal of Information Technology Education 6, 1-21. 